\title{
Adsorption of Perfluoroalkyl Compounds onto Microporous Agave Sisalana Activated Carbon Fibre
}

\author{
Serge M. Imwer, John B.N. Mudumbi, Seteno K.O. Ntwampe, Elizabeth I. Omodanisi, Adegbenro P. \\ Daso, Marshall S. Sheldon and Sebusi Odisitse
}

\begin{abstract}
Perfluoroalkyl compounds (PFCs) have been shown to cause harmful effects on the environment and human health. A major concern is their wide range of uses in consumer products which have been detected in food and drinking water. The study reported the removal of these contaminants using a microporous activated carbon fibre (ACF) made from an indigenous plant, Agave sisalana, widely available across sub-Saharan Africa, by using electro-physicochemical methods. An electro-physicochemical adsorption regime was designed, to facilitate the rapid adsorption of PFOS and PFOA from contaminated drinking water in an electrolytic cell. Initially, adsorption studies $(\mathrm{n}=48)$ using sonication $(20 \mathrm{kHz})$ in batch systems indicated efficient removal of PFOA and PFOS within $120 \mathrm{~min}$, with numerous samples $(\mathrm{n}=14)$ achieving complete removal for both PFOA and PFOS. The minimum removal rates observed were $65.55 \%$ for PFOA and $95.92 \%$ for PFOS.
\end{abstract}

Keywords - activated cacbon fibre, Adsoption, Agave sisalana, Perfluoroalkyl compounds.

\section{INTRODUCTION}

Perfluorooctanoic acid (PFOA) and perfluorooctane sulfonate (PFOS) are inert chemical compounds that have been

Manuscript received September 10, 2019. This work was supported by the Cape Peninsula University of Technology (CPUT) under Grant RK16.

S.M Imwer was with the Bioresource Engineering Research Group (BioERG), Department of Biotechnology, Faculty of Applied Sciences, Cape Peninsula University of Technology, Keizersgracht and Tennant Street, Zonnebloem, P.O. Box 652, Cape Town, 8000, South Africa.

J.B.N. Mudumbi is with the Bioresource Engineering Research Group (BioERG), Faculty of Applied Sciences, Department of Biotechnology, Cape Peninsula University of Technology, Keizersgracht and Tennant Street, Zonnebloem, P.O. Box 652, Cape Town, 8000, South Africa.

S.K.O. Ntwampe is the founder of Bioresource Engineering Research Group (BioERG), Faculty of Engineering and the Built Environment, Department of Chemical Engineering, Cape Peninsula University of Technology, PO Box 1906, Bellville, 7535, South Africa.

E.I. Omodanisi is with the Bioresource Engineering Research Group (BioERG), Department of Biotechnology, Faculty of Applied Sciences, Cape Peninsula University of Technology, Keizersgracht and Tennant Street, Zonnebloem, P.O. Box 652, Cape Town, 8000, South Africa.

A.P. Daso is with the Department of Environmental, Water and Earth Sciences, Faculty of Science, Tshwane University of Technology, Pretoria 0083, South Africa.

M.S. Sheldona is with the Faculty of Engineering and the Built Environment, Department of Chemical Engineering, Cape Peninsula University of Technology, PO Box 1906, Bellville, 7535, South Africa

S. Odisitse is with the Faculty of Science, Department of Chemistry and Forensic Sciences, Botswana International University of Sciences and Technology, P/bag x16, Palapye, Botswana, BW determined to be bio-accumulative, persistent and major environmental pollutants in water. They have been used in many industrial processes and are found in Teflon-based cookware, drinking tap water and various media (Herrera \& Alvarez, 2008). As these compounds are highly soluble in water, they contaminate environmental water sources, that is, ground and surface waters (Yu et al., 2009). To date, thousands of PFCs have been discovered, but PFOA and PFOS have been reported to be the most harmful to humans (OECD, 2002). PFCs have extensively been used as lubricants, surfactants, fire retardants, adhesives, paper-coats, refrigerants, propellants and agro-chemicals even with their detrimental effect on humans and the environment.

The unique properties of PFOA and PFOS, which make them suitable for various industrial applications and non-biodegradability, are the lack of carbon-hydrogen $(\mathrm{C}-\mathrm{H})$ bonds in their structure, which are replaced by carbon-fluorine (C-F) bonds (Renner, 2001; Qiu, 2007). As a result, these compounds are thermodynamically stable, which makes them non-biodegradable.

\section{Perfluoro-octanoate acid}

\section{Perfluoro-octane sulfonate}
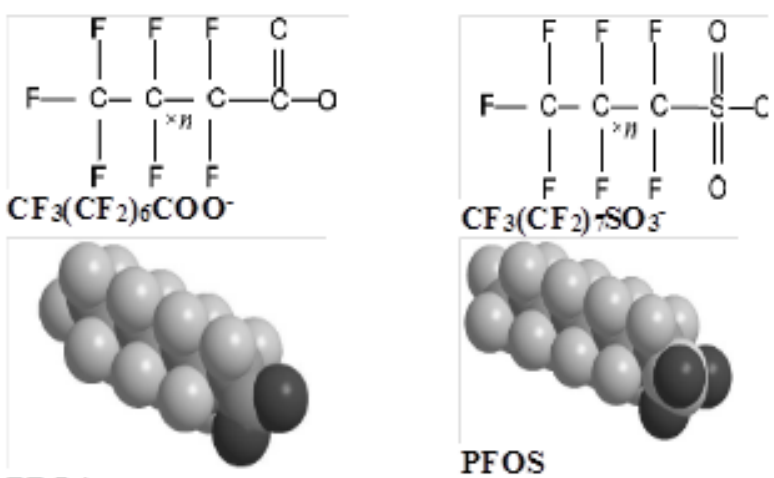

PFOS

PF OA

Fig. 1. Structure of PFOA and PFOS (Qiu, 2007)

Their presence in the environment has been reported in several countries (Rovira et al., 2019; Torre et al., 2019) and recently in South Africa (Mudumbi, 2013). For example, in a study conducted in the USA, the presence of PFOA in potable water in Washington and Virginia was determined to be in the range of 1.9 to $4.9 \mathrm{ng} / \mathrm{L}$ (Bartell et al., 2010), with the median 
PFOA concentration in human sera being $8.75 \mathrm{ng} / \mathrm{L}$ (range 4 to $21 \mathrm{ng} / \mathrm{L}$ ) (Steenland et al., 2010), indicating a possible continuous exposure or ingestion. Similarly, the presence of PFOS and PFOA was detected and quantified in tap water in China, with the concentration range of $<0.1$ to $14.8 \mathrm{ng} / \mathrm{L}$ and $<0.1$ to $45 \mathrm{ng} / \mathrm{L}$ for PFOS and PFOA, respectively (Jin et al., 2009).

A similar survey was done in South Africa (SA), where the presence of PFOS and PFOA in maternal serum and cord blood of South African women was determined in a range of 0.5 to 16 $\mathrm{ng} / \mathrm{mL}$ and 0.4 to $8.5 \mathrm{ng} / \mathrm{mL}$, respectively (Hanssen et al., 2010). This prompted a study to assess PFOA and PFOS concentrations in the drinking water of the Western Cape, South Africa (Booi, 2013). The results indicated a widespread contaminate of PFOA and PFOS in drinking water, including river water used to irrigate agricultural produce (Mudumbi, 2013). The major route of these pollutants in terms of environmental contamination is through contaminated water sources such as wastewater discharged by industries which have to apply products containing these substances during the manufacturing process. Several studies have been done to assess their prevalence in natural water sources such as river-, sea-, and rainwater (Melzer et al., 2010). Similarly, Skutlarek et al. (2006) carried out a study in two German rivers; Rhine River and Moehne River, canals and drinking waters of the Ruhr catchment area to quantify the concentration of perfluorinated surfactants in surface and drinking waters, where 12 different PFCs, including PFOA and PFOS, were found.

Various studies have published information on the removal of PFOS and PFOA by adsorption. For instance, a comparison was made whereby powdered activated carbon (PAC), granulated activated carbon (Ounas et al., 2009), and ion exchange resin (AI400) were evaluated for the removal of PFOA and PFOS from water. It was found that the adsorbent size influenced the sorption kinetics with activated carbon (AC) being effective in comparison with ion exchange (Yu et al., 2009).

Agave sisalana (sisal) is a tropical plant which falls under the genus Agave. This plant is principally monocarpic (i.e. reproducing only once after several years and then dying). Thus, A. sisalana is of considerable ecological (as keystone species) and economic importance as it is used as a raw material for several industries in various countries (Good-Avila et al., 2006). It is an important cordage fibre-yielding plant that is drought resistant and can withstand extreme dry conditions. Studies have shown that sisal fibres can be carbonised to produce a silver supported activated carbon fibre (Chen et al., 2005). Similarly, sisal waste was also used as a feedstock to produce ACF by a chemical activation process with $\mathrm{K}_{2} \mathrm{CO}_{3}$ as the activating agent under $\mathrm{N}_{2}$ flow (Mestre et al., 2011). The result revealed that adsorption of PFOA and PFOS on ACF was a monolayer adsorption type phenomenon.

The study evaluated the the removal of PFOS and PFOA from contaminated water using activated carbon fibre obtained from Agave sisalana.

\section{MATERIALS AND MethodS}

\section{A. Samples Collection and Processing}

This process was performed according to previous studies (Conter, 1903; Chen et al., 2005). As such, after sisal reached maturity (3 years), the lower and older leaves were removed close to the head, and scraped one by one, using a scraper. The fibres were extracted, cleaned and then dried. The drying process consisted of hanging the fibres in the sun, to allow them to lose their lustre. Nevertheless, the fibres were kept straight and cleaned to avoid mixing of the fibres and tuft.

\section{B. Manufacturing of activated carbon fibre (ACF)}

Different reagents were sprayed onto the sisal fibres. After spraying along the fibre length, samples were placed in an oven at a temperature of $110^{\circ} \mathrm{C}$ for about an hour until completely dry. The process was repeated until a total volume of $10 \mathrm{ml}$ of the reagent was sprayed. Long sisal fibres were then cut to a length of $3 \mathrm{~mm}$, loaded into ceramic boats, packed in a tubular furnace and pyrolysed at a required temperature under nitrogen $\left(\mathrm{N}_{2}\right)$. However, since the carbonization and the chemical activation were combined, the purging gas was switched to carbon dioxide $\left(\mathrm{CO}_{2}\right)$ when the activation temperature was reached.

Once activation had taken place, a period of time elapsed, the temperature was then reduced under $\mathrm{N}_{2}$ ) to room temperature. The ACF obtained was then washed with $6 \mathrm{~L}$ of warm distilled water. During the washing process, bromothymol blue was used as an indicator to assess the neutrality of the recovered rinsing water. Samples were then dried in an oven overnight. The final product (ACF) were sealed in a bag $(5 \times 6$ $\mathrm{cm})$ using heat at a varying temperature from $450-650{ }^{\circ} \mathrm{C}$. The concentration of the activation reagents is shown in Table 1, while Figure 2.

TABLE 1: CONCENTRATION OF DIFFERENT REAGENTS USED FOR THE ACTIVATION PROCESS

\begin{tabular}{llllll}
\hline $\begin{array}{l}\text { Activation } \\
\text { agent }\end{array}$ & \multicolumn{5}{c}{ Concentration } \\
\hline $\mathrm{KOH}$ & $21.6 \mathrm{M}$ & $4.32 \mathrm{M}$ & $2.16 \mathrm{M}$ & $1.08 \mathrm{M}$ & $0.54 \mathrm{M}$ \\
$\mathrm{NaOH}$ & $25 \mathrm{M}$ & $5 \mathrm{M}$ & $2.5 \mathrm{M}$ & $1.25 \mathrm{M}$ & $0.625 \mathrm{M}$ \\
$\mathrm{ZnCl}_{2}$ & $31.8 \mathrm{M}$ & $6.36 \mathrm{M}$ & $3.18 \mathrm{M}$ & $1.59 \mathrm{M}$ & $0.795 \mathrm{M}$ \\
$\mathrm{H}_{3} \mathrm{PO}_{4}$ & $14.6 \mathrm{M}$ & $2.92 \mathrm{M}$ & $1.46 \mathrm{M}$ & $0.73 \mathrm{M}$ & $0.365 \mathrm{M}$ \\
\hline
\end{tabular}

Control pure sisal/pyrolysed sisal: $\mathrm{KOH}-121 \mathrm{~g} / 100 \mathrm{ml}$ at $25^{\circ} \mathrm{C}$ (saturated); $\mathrm{NaOH}-100 \mathrm{~g} / 100 \mathrm{ml}$ at $25^{\circ} \mathrm{C}$ (saturated); $\mathrm{ZnCl}_{2} 432 \mathrm{~g} / 100 \mathrm{ml}$ at $25^{\circ} \mathrm{C}$ (saturated); $\mathrm{H}_{3} \mathrm{PO}_{4}$ - Used as is and the dilution of 1/5, 1/10, 1/20, $1 / 40$ thereafter for all of them

\section{A. Preparation of PFOS and PFOA contaminated water}

A 2 L polypropylene (PP) container was washed with methanol, to avoid any PFC contamination, then rinsed with Milli-Q water (Mastalerz et al., 2011). Two litres of distilled water were placed in $2 \mathrm{~L}$ PP bottle; to which $0.1 \mu \mathrm{L}$ of PFOA and PFOS, at the concentration of $2 \mathrm{~g} / \mathrm{L}$ each, was added into the distilled water to produce a solution of polluted water at a concentration of $100 \mathrm{ng} / \mathrm{L}$ of PFOA and PFOS. The synthetic water used, was based on raw and treated drinking assessments from another study (Booi, 2013), whereby PFC concentrations were determined in the range up to $40 \mathrm{ng} / \mathrm{L}$ and $100 \mathrm{ng} / \mathrm{L}$ observed by Mudumbi et al. (2014), in river water, for both PFOA and PFOS. 


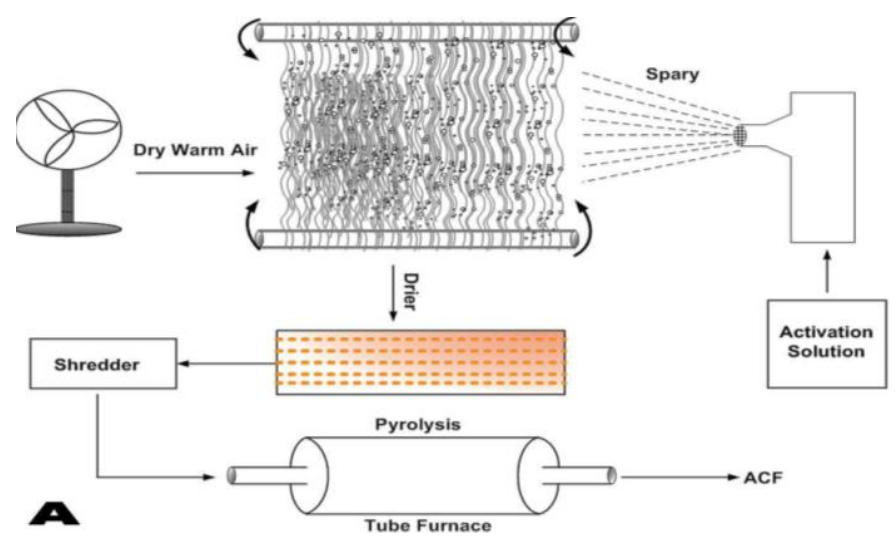

Fig. 2. Schematic representation of the preparation method for ACF using Agave Sisalana

\section{B. Surface area characterization}

Analyses were done on a 3Flex Surface Characterization Analyzer from Micromeritics Instrument Corporation. Prior to analysis, the samples were degassed using a Vacprep 061 at $250^{\circ} \mathrm{C}$ for 24 hours under vacuum (Webb \& Orr, 1997). $\mathrm{CO}_{2}$ was used as the adsorbate gas at a temperature of $0^{\circ} \mathrm{C}$. The different models used for surface characterization and the surface area obtained using different feedstock can found in previous work (Imwer, 2014). The surface area models used tend to over-estimate surface properties during analysis (Results), therefore, the specific surface area for the ACF was quantified using the Dubinin-Astakhov isotherm with a relative pressure $\left(\mathrm{P} / \mathrm{P}_{0}\right)$ up to 0.01 . The sample mass was between 0.2 to $0.3 \mathrm{~g}$.

\section{Adsorption studies}

\section{1) Physico-chemical assisted adsorption studies}

Physico-chemical assisted adsorption was performed using $150 \mathrm{ml}$ of contaminated water in a $250 \mathrm{~mL}$ polypropylene (PP) beaker without $\mathrm{pH}$ adjustment; then an ACF bag containing $0.57 \mathrm{~g}$ of A. Sisalana was immersed into the polluted water with subsequent sonication. The sonicator was set at $20 \mathrm{kHz}$, whichprobe was rinsed with $99 \%$ methanol and Milli-Q water after each experiment before processing new samples. The samples were sonicated for 2 hours. Thereafter, the ACF bags were dried in the oven at $70^{\circ} \mathrm{C}$, while a $10 \mathrm{ml}$ solution was taken from the bulk solution for analysis. The sample solution for analysis was filtered $(0.22 \mu \mathrm{m})$ and stored in the refrigerator at 4 ${ }^{\circ} \mathrm{C}$ prior the analysis, which was performed using a liquid chromatography system, combined with tripartite quadrupole linear ion trap tandem mass spectrometer (LC-MS/MS), but only after Solid Phase Extraction (SPE) was executed. LC-MS/MS was performed on a Ultimate 3000 Dionex HPLC system (Dionex Softron, Germering, Germany), equipped with a binary solvent manager and auto sampler, coupled to a Brucker ESI Ion Trap Mass Spectrometer (Bruker Daltonik $\mathrm{GmbH}$, Germany). The products were separated by reversedphase chromatography on a Waters Sunfire C18 column $5 \mu \mathrm{m}$, $4.6 \times 150 \mathrm{~mm}$ (Dublin, Ireland) using gradient elution at a flow rate of $0.8 \mathrm{ml} \mathrm{min}^{-1}$, an injection volume of $10 \mu \mathrm{L}$ and an oven temperature of $30^{\circ} \mathrm{C}$. The gradient was set up as follows: $64 \%$
A to $44 \% \mathrm{~A}(12 \mathrm{~min}) ; 44 \% \mathrm{~A}$ to $1 \% \mathrm{~A}(12-13 \mathrm{~min}) ; 64 \% \mathrm{~A}$ (13.1-20 min); solvent $\mathrm{A}-5 \mathrm{mM}$ ammonium acetate in water, solvent B - acetonitrile. MS spectra were acquired in a negative mode using the full scan mode with dual spray for reference mass solution. Electrospray voltage was set to $-3500 \mathrm{~V}$. Dry gas flow was set at $91 \mathrm{~min}^{-1}$ with a temperature of $350{ }^{\circ} \mathrm{C}$ and the nebuliser gas pressure was set to $347.96 \mathrm{KPa}$. The compounds were quantified using Quant Analysis software. The cumulative loading for the adsorption was determined using the mathematical expression in Eq. 1:

$q_{s t}=\frac{x}{m}=\frac{\left.\llbracket c_{\mathrm{l}}-c_{\mathrm{s}}\right] \mathrm{v}_{\mathrm{O}}}{\text { wolume conversion factor }}$

Where $X$ - is the amount of PFOA/PFOS adsorbed onto the ACF, $m-$ is the mass of the adsorbent (ACF), $C_{i}-$ is the initial concentration of PFOA/PFOS in solution, $C_{s}-$ is the amount of residual PFOA/PFOS in solution, $V_{r}-$ is the volume of the PFOA/PFOS contaminated water used during adsorption, and $q_{s t}$ - is the cumulative loading parameter for PFOA/PFOS adsorption. This mathematical expression was also used for the determination of PFOA/PFOS adsorption using an Electro-physico-chemical method.

\section{2) Electro-physico-chemical assisted adsorption}

A neckless $250 \mathrm{~mL}$ PP bottle containing $150 \mathrm{~mL}$ of contaminated water was used as an electrolytic - type cell, where the electrodes were $55 \mathrm{~mm}$ distant from each other and the ACF bag containing $0.57 \mathrm{~g}$ of A. Sisalana being placed at the anode. The cathode was made of stainless steel while the anode was plated with a platinum layer. The direct current used for electrolysis was 12 volt $(V)$. During electrolysis, sonication was also applied, with samples being taken every 20 minutes for a period of 2 hours.

\section{RESULTS AND DISCUSSION}

\section{A. Manufacturing of activated carbon fibre (ACF)}

Activated carbon fibre (ACF) was synthesised from Sisal fibres via the spraying technique. Fig. 3 represent a sample obtained using the spray method. Although the spray scattered the activation chemical solutions on the fibre, the erosive effect of the method suggested that intermittent application of the spray was necessary, with a drying effect for immediate drying of the droplets when they are on the surface of the sisal, resulting in the formation of pores. A comparative analysis was made using Scanning Electron Microscopy (SEM) monographs of the fibre obtained in this study with other SEM monographs reported in published works (Phan et al., 2006; Tan et al., 2007; Tan et al., 2008). These samples were very similar, with the fibre obtained from this study showing a highly porous external and internal structure of the fibre. 


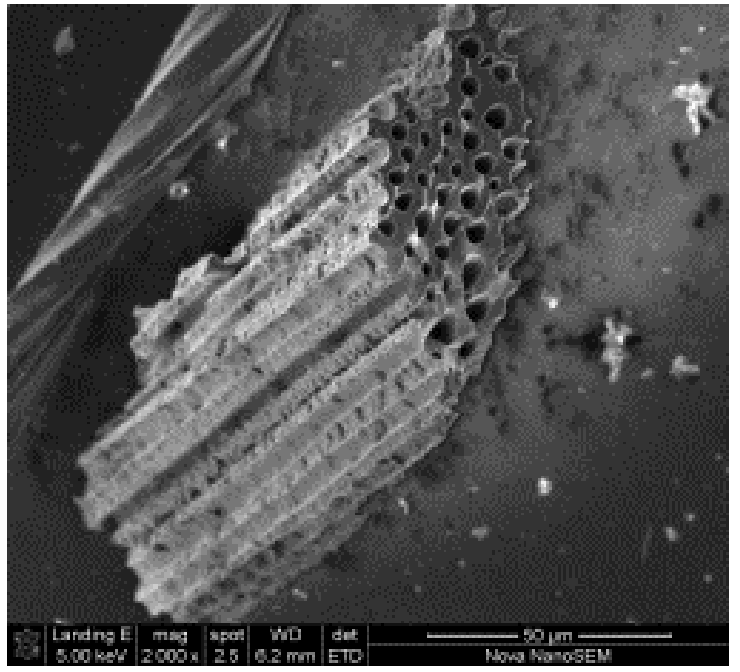

Fig. 3. SEM micrograph of sisal fibre after being pyrolysed by applying the activation reagents.

Table 2 how the activation reagent were selected, while listed the operating temperature of the furnace during ACF production and the yield obtained.

TABLE II: SELECTION OF THE OPTIMUM ACTIVATION AGENT

\begin{tabular}{|c|c|c|c|c|c|c|}
\hline \multicolumn{2}{|c|}{ Parameters/Reagents } & \multirow{2}{*}{$\begin{array}{l}{ }^{\mathbf{y}} \mathbf{Z n C l}_{\mathbf{2}} \\
94.2-100\end{array}$} & \multirow{2}{*}{ 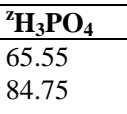 } & \multicolumn{3}{|c|}{${ }^{\mathrm{x}} \mathrm{KOH}$} \\
\hline \multirow{2}{*}{ o゚ } & PFOA & & & - & $\begin{array}{l}75,57 \\
99.19\end{array}$ & - \\
\hline & PFOS & $98.4-99.7$ & $\begin{array}{l}95.92 \\
98.79\end{array}$ & - & $\begin{array}{l}98.74 \\
99.74\end{array}$ & - \\
\hline \multirow{3}{*}{ 泀 } & Temperature & $650-850$ & $650-850$ & & 650 & \\
\hline & $\begin{array}{l}\text { Activation } \\
\text { time }\end{array}$ & $\begin{array}{l}45 \mathrm{~min}-3 \mathrm{hrs} \\
28 \mathrm{~min}\end{array}$ & $\begin{array}{l}45 \mathrm{~min} \\
3 \mathrm{hrs}\end{array}$ & - & $1 \mathrm{hr} 53 \mathrm{~min}$ & \\
\hline & $\begin{array}{l}\text { Activation } \\
\text { reagent conc. } \\
\text { (M) }\end{array}$ & 1.59 & 0.73 & & 0.54 & \\
\hline$\%$ Yield & & 32 & 32.7 & & 33.8 & \\
\hline
\end{tabular}

\section{B. PFOA and PFOS adsorption onto AFC using sonication}

During the experiments, concentrations of PFOA and PFOS in the polluted water samples were $100 \mathrm{ng} / \mathrm{L}$ and $100 \mathrm{ng} / \mathrm{L}$, respectively. Table 2 displays the experimental results obtained from the adsorption of PFOA and PFOS assisted with an ultrasound probe. These experiments were performed under the following conditions: duration: $120 \mathrm{~min}$; amplitude: $20 \mathrm{kHz}$; power: $28 \mathrm{~W} ; 220 \mathrm{~J}$, with the final temperature of the water being $35^{\circ} \mathrm{C}$.

The ACF prepared under different pyrolysis conditions performed differently. However, the removal efficiency of PFOS was the most consistent, albeit available evidence reporting that PFOA is largely easier to be adsorbed than PFOS. However, in the present study, we strongly believe that sonication assists or plays a role in the physical attachment of a contaminant to a solid matrix. As such, since PFOA and PFOS could attach to the surface of the ACF by physical means, the same physical forces could also result in the adsorption-desorption cyclic phenomena, for which a contaminant with weak Van der Waal's forces could largely remain within the solution in which it was initially present. As previously explained, the formation of cavitations can, therefore, result in the desorption of the adsorped PFCs.

For this study, this removal of the two pollutants was not complete for both PFCs in the samples. This led us to presume that each ACF sample had a different affinity to PFOA and PFOS, perhaps with the reagent used for its activation playing a major role.

\section{Surface area determination}

With regard to the characterisation of ACF samples produced during this study, four models were used to evaluate the surface area, pore size and pore volume. These models were: (i) Brunauer-Emmett-Teller, (ii) Horvath-Kawazoe, (iii) Dubinin-Radushkevich and (iv) Dubinin-Astakhov. Based on the report of the analysis, it was found that the samples produced in this study had mostly micropores and almost no mesopores. Of the models mentioned above, the Dubinin-Astakhov isotherm was used to evaluate the micropore surface area for this study, compared with other studies where specifications were given of the stratification of AC pores, such as macropores (> $500 \AA)$, mesopores $(20-500 \AA)$ and micropores (< $20 \AA$ Å) (Pelekani \& Snoeyink, 1999), with sizing related to the pore's diameter. In order to perform this analysis, low-pressure $\mathrm{CO}_{2}$ adsorption at $0^{\circ} \mathrm{C}$ was used to describe the pore size and surface characteristics of the ACF. The Dubinin-Astakhov equation can be used to linearise adsorption data that generate curved Dubinin-Astakhov plots. Micropore volumes found using the Dubinin-Astakhov equation agreed with the total volume generated by the $\mathrm{N}_{2}$ adsorption method which occurs at $-196^{\circ} \mathrm{C}$ for all activated carbon studies (Ghosal \& Smith, 1996).

The ACF prepared with $\mathrm{ZnCl}_{2}$ at the concentration of $1.59 \mathrm{M}$ had a micropore surface area of $1036 \mathrm{~m}^{2} / \mathrm{g}$ with a limiting volume of $0.32 \mathrm{~cm}^{3} / \mathrm{g}$, while the one prepared with $\mathrm{KOH}$ at the concentration of $0.54 \mathrm{M}$ had a micropore surface area of $1285 \mathrm{~m}^{2} / \mathrm{g}$ with a limiting volume of $0.39 \mathrm{~cm}^{3} / \mathrm{g}$ see Table 3 . In a study on the production of activated carbon from olive industry waste using $\mathrm{NaOH}, \mathrm{Na}_{2} \mathrm{CO}_{3}, \mathrm{HCl}, \mathrm{H}_{2} \mathrm{SO}_{4}, \mathrm{H}_{3} \mathrm{PO}_{4}$ and $\mathrm{KOH}$, the later (i.e. $\mathrm{KOH}$ ) was reported to be the best activation reagent when it comes to the adsorption of trace contaminants in water (Ounas et al., 2009). In this study, the focus was on ACF made from $\mathrm{KOH}$, which was then used for, electro-physico-chemical adsorption kinetics.

TABLE III. PHYSICAL PROPERTIES OF THE AGAVE SISALANA ACF

\begin{tabular}{l|c|c}
\hline Property & $\mathrm{ZnCl}_{2}[1.59 \mathrm{M}]$ & $\mathrm{KOH}[0.54 \mathrm{M}]$ \\
\hline Surface area $\left(\mathrm{m}^{2} \mathrm{~g}^{-1}\right)^{*}$ & 1036.76 & 1285.83 \\
Micropore volume $\left(\mathrm{cm}^{3} \mathrm{~g}^{-1}\right)$ & 0.097 & 0.13 \\
Total pore volume $\left(\mathrm{cm}^{3} \mathrm{~g}^{-1}\right)$ & 0.32 & 0.39 \\
Microporosity (\%) & 30.36 & 34.16 \\
Average micropore width $(\AA)$ & $(3.7-8.04)$ & $(3.7-8.21)$ \\
\hline *Determined using Dubinin - Astakhov Isotherm
\end{tabular}

Activated carbon fibre emanating from sisal prepared with $\mathrm{ZnCl}_{2}$ and $\mathrm{KOH}$ provided micropores with a suitable width for 
the adsorption of PFOA and PFOS. In this study, ACF from sisal produced a micropore- material with a distribution pore of about $8 \AA$. This was in agreement with the previous report from by Chen et al. (2005), who achieved an ACF with a similar pore diameter.

\section{Removal of PFOA and PFOS from drinking water using} Agave sisalana activated carbon fibre

In this section, experimental data proved that PFOA and PFOS were removed from polluted water using ACF produced from Agave sisalana treated with $\mathrm{KOH}$ in an electro-physico-chemical system. Samples $1\left(\mathrm{ZnCl}_{2}-1.59 \mathrm{M}\right)$ and $2(\mathrm{KOH}-0.54 \mathrm{M})$ were used. Both sorbents showed asignificant pollutant removal.

\section{TABLE IV. REMOVAL OF PFOA AND PFOS FROM TAP POLLUTED} WATER WITH ACF

\begin{tabular}{|c|c|c|c|c|c|c|}
\hline \multirow{2}{*}{$\begin{array}{l}\text { Sample } \\
\text { Name }\end{array}$} & \multirow{2}{*}{$\begin{array}{l}\text { PFOA (ng/L) } \\
\text { Calc. Conc. }\end{array}$} & \multirow{2}{*}{$\begin{array}{l}\text { PFOS (ng/L) } \\
\text { Calc. Conc. }\end{array}$} & \multirow{2}{*}{$\begin{array}{l}\text { Time } \\
(\min )\end{array}$} & \multicolumn{3}{|c|}{$\%$ removal } \\
\hline & & & & PFOA & PFOS & \\
\hline KFP0 & 106.141 & 100.145 & 0 & 0 & 0 & [9] \\
\hline KF1 & 92.839 & 77.365 & 20 & 12.532 & 22.746 & \\
\hline KF2 & 76.391 & 61.523 & 40 & 28.027 & 38.565 & \\
\hline KF3 & 72.185 & 52.785 & 60 & 31.990 & 47.290 & \\
\hline KP4 & 72.090 & 51.891 & 80 & 32.080 & 48.183 & {$[10$} \\
\hline KF5 & 71.110 & 49.070 & 100 & 33.004 & 51.000 & \\
\hline KF6 & 70.388 & 47.126 & 120 & 33.684 & 52.941 & \\
\hline
\end{tabular}

\section{CONCLUSION}

The manufacture of activated carbon by chemical activation requires the use of chemicals. Samples prepared with $\mathrm{KOH}$ present the best percentage removal for PFOA and PFOS, where the satisfactory concentration for $\mathrm{KOH}$ was $0.54 \mathrm{M}$. This study demonstrated that an activated carbon fibre-based Agave sisalana successfully removed PFOA and PFOS from polluted tap water.

\section{ACKNOWLEDGMENT}

The technical officers of the Department of Chemical Engineering and the Faculty of Applied Sciences, Hannelene Small, Alwyn Bester and Lorna Marshall, are acknowledged for their assistance.

\section{REFERENCES}

[1] O.V. Herrera, and S.R. Alvarez, "Removal of perfluorinated surfactants by sorbtion onto granular activated carbon, zeolite and sludge". Chemosphere, vol.72, pp.1588 - 1593. 2008. https://doi.org/10.1016/j.chemosphere.2008.04.029

[2] Q. Yu, R. Zhang, S. Deng, J. Huang, and G. Yu, "Sorption of perfluorooctane sulfonate and perfluorooctanoate on activated carbons and resin: kinetic and isotherm study". Water Research, vol.43, pp. 1150-1158. 2009. https://doi.org/10.1016/j.watres.2008.12.001

[3] Organisation Economic co-operation and Development (OECD). Co-operation existing chemicals hazard assessment of perfluorooctane sulfonate (PFOS) and its salts. ENV/JM/RD(2002)17/Final. Paris. 2002.
[4] R. Renner, "Growing concern over perfluorinated chemicals". Environmental Science and Technology, vol.35, pp. 154A-160A. 2001. https://doi.org/10.1021/es012317k

[5] Y. Qiu, "Study on treatment technologies for perfluorochemicals in wastewater". PhD thesis, Kyoto University. 2007.

[6] J. Rovira, M. Á. Martínez, R.P. Sharma, T. Espuis, M. Nadal, V. Kumar, D. Costopoulou, I. Vassiliadou, L. Leondiadis, J.L.Domingo, and M.Schuhmacher, Prenatal exposure to PFOS and PFOA in a pregnant women cohort of Catalonia, Spain. Environmental research, vol.175, pp.384-392. 2019. https://doi.org/10.1016/j.envres.2019.05.040

[7] A.de la Torre, I. Navarro, P. Sanz, and María, M. de los Ángeles, "Occurrence and human exposure assessment of perfluorinated substances in house dust from three European countries." Science of The Total Environment, vol.685, pp.308-314. 2019. https://doi.org/10.1016/j.scitotenv.2019.05.463

[8] J. B. N. Mudumbi, S. K. O. Ntwampe, F. M. Muganza, and J. O. Okonkwo. "Perfluorooctanoate and perfluorooctane sulfonate in South African river water." Water Science and Technology vol.69, no. 1. 185-194. 2013.

https://doi.org/10.2166/wst.2013.566

[9] S. M. Bartell, A. M. Calafat, C. Lyu, K. Kato, P.B. Ryan, and K.Steenland, "Rate of decline in serum PFOA concentrations after granular activated carbon filtration at two public water systems in Ohio and West Virginia". Environmental Health Perspectives, vol.118, pp. 222-228. 2010. https://doi.org/10.1289/ehp.0901252

[10] K. Steenland, S.Tinker, A. Shankar, and A. Ducatman, "Association of perluorooctanoic acid (PFOA) and perfluorooctane sulfonate (PFOS) with uric acid among adults with elevated community exposure to PFOA". Environmental and Health Perspectives, vol.118, pp. 229-233. 2010

https://doi.org/10.1289/ehp.0900940.

[11] H. Y., Jin, W. Liu, I. Sato, F.S. Nakayama, K. Sasaki., N. Saito, and S Tsuda, "PFOS and PFOA in environmental and tap water in China". Chemosphere, vol. 77, pp. 605-611. 2009. https://doi.org/10.1016/j.chemosphere.2009.08.058

[12] L. Hanssen, H. Rollin, J.O. Odland, M.K. Moe, and T.M. Sandanger, "Perfluorinated compounds in maternal serum and cord blood from selected areas of South Africa: results of a pilot study". Journal of Environmental Monitoring, vol.12, pp. 1355-1361. 2010. https://doi.org/10.1039/b924420d

[13] X. Booi, "Perfluorinated compounds and trihalomethanes in drinking water sources of the Western Cape, South Africa". Master thesis. Dept. Chem. Eng. Cape Peninsula University of Technology. 2013.

[14] D. Melzer, N. Rice, M.H. Depledge, W.E. Henley, and T.S. Galloway, "Association between serum perfluorooctanoic acid (PFOA) and thyroid disease in the NHANES study". Environmental Health Perspectives, vol.118, pp. 686-692. 2010 https://doi.org/10.1289/ehp.0901584

[15] D. Skutlarek, M. Exner, and H. Färber. "Perfluorinated surfacts in surface and drinking waters". University of Bonn, Institute of Hygiene and Public Health, Environmental Science Pollution Research. vol.13, no 5. pp. 149-158. Sept. 2006. https://doi.org/10.1065/espr2006.07.326

[16] A. Ounas, N. Bergach, K. Ennaciri, A. Yaacoubi, and A. Bacaoui, 2009. "Preparation des charbons actifs a partir des dechets de l'industrie oleicole [Online]. Available: http://agrimaroc.net/agdumed2009/Ounas_Preparation_charbons_actifs _dechets_industrie_oleicole.pdf [Accessed 31 January 2014].

[17] S.V. Good-Avila, V.Souza, B.S. Gaut, and L.E. Eguiarte, "Timing and rate of speciation in Agave (Agavaceae). Proceedings of the National Academy of Sciences, vol.103, pp. 9124-9129. 2006. 
https://doi.org/10.1073/pnas.0603312103

[18] S.Chen, J. Liu, and H. Zeng, "Structure and antibacterial activity of silver-supporting activated carbon fibers". Journal of Materials Science, vol.40, pp. 6223-6231. 2005. https://doi.org/10.1007/s10853-005-3149-3

[19] A.S. Mestre, A.S. Bexiga, M. Proença, M. Andrade, M.L. Pinto, I. Matos, I.M. Fonseca, and A.P. Carvalho, “Activated carbons from sisal waste by chemical activation with $\mathrm{K} 2 \mathrm{CO} 3$ : kinetics of paracetamol and ibuprofen removal from aqueous solution". Bioresource Technology, vol.102, pp. 8253-8260. 2011 https://doi.org/10.1016/j.biortech.2011.06.024

[20] A. W. Tan, B.H. Hameed, and A.L. Ahmad, "Equilibrium and kinetic studies on basic dye adsorption by oil palm fibre activated carbon". Chemical Engineering Journal, vol.127, pp. 111-119. 2007. https://doi.org/10.1016/j.cej.2006.09.010

[21] M. M. Vargas, C.A. Garcia, E.M. Reis, E. Lenzi, W.F. Costa, and V.C. Almeida, "NaOH-activated carbon from flamboyant (Delonix regia) pods: Optimization of preparation conditions using central composite rotatable design". Chemical Engineering Journal, vol.162, pp. 43-50. 2010. https://doi.org/10.1016/j.cej.2010.04.052

[22] H. Hameed, A.T.M. Din, and A.L. Ahmad, "Adsorption of methylene blue onto bamboo-based activated carbon: kinetics and equilibrium studies". Journal of Hazardous Materials, vol.141, pp. 819-825. 2007. https://doi.org/10.1016/j.jhazmat.2006.07.049

[23] F.E. Conter, 1903. The cultivation of sisal in Hawaii, Hawaiian Gazette Company.

[24] M. Mastalerz, M.W. Schneider, I.M. Oppel, and O.A. Presly, "Salicylbisimine cage compound with high surface area and selective $\mathrm{CO} / \mathrm{CH} 4$ adsorption". Angewandte Chemie International Edition, vol.50, pp. 1046-1051, 2011. https://doi.org/10.1002/anie.201005301

[25] J. B. N., Mudumbi, S. K. O., Ntwampe, M. F. Muganza, and J. O. Okonkwo, "Perfluorooctanoate (PFOA) and perfluorooctane sulfonate (PFOS) in South African river water. Water Science and Technology, vol.69, pp. 185-194. 2014. https://doi.org/10.2166/wst.2013.566

[26] P. A. Webb, and C. Orr, "Analytical methods in fine particle technology", Micromeritics Norcross, GA. 1997.

[27] S.M. Imwer, "Adsorption of perfluorinated water contaminants on microporous agave sisalana activated carbon fibre". Master thesis. Dept. Chem. Eng. Cape Peninsula University of Technology. 2014.

[28] N. H.Phan, S Rio, C. Faur, L. Le Coq, P. Le Cloirec, and T. H. Nguyen, "Production of fibrous activated carbons from natural cellulose (jute, coconut) fibers for water treatment applications". Carbon vol. 44, pp. 2569-2577. 2006. https://doi.org/10.1016/j.carbon.2006.05.048

[29] A. W.Tan, A. L. Ahmad, and B. H. Hameed, "Adsorption of basic dye using activated carbon prepared from oil palm shell: batch and fixed bed studies". Desalination, vol.225, pp. 13-28. 2008. https://doi.org/10.1016/j.desal.2007.07.005

[30] C. Pelekani, and V.L.Snoeyink, "Competitive adsorption in natural water: role of activated carbon pore size". Water Research, vol.33, pp. 1209-1219. 1999. https://doi.org/10.1016/S0043-1354(98)00329-7

[31] R. Ghosal, and D. Smith, "Micropore characterization using the Dubinin-Astakhov equation to analyze high pressure CO2 (273 K) adsorption data”. Journal of Porous Materials, vol.3, pp. 247-255. 1996. https://doi.org/10.1007/BF01137914

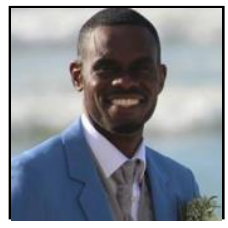

Serge Imwer Mapan graduated with a Masters of Technology degree in Chemical Engineering cum laude at the Cape Peninsula University of Technology in 2015 under the tutelage of Profs SKO Ntwampe and MS Sheldon including Dr S Odisitse. He was part of the development of the perfluoroalkyl contaminants in the Bioreseorce Engineering Research Group. 